\title{
The effect of potassium humate on the body of animals in the form of a feed additive
}

Bailina G.E. ${ }^{1}$, Ermagambet B.T. ${ }^{1}$, Kassenova J.M. $^{1}$, Kuchar E.V. $^{2}$

${ }^{1}$ TOO Institute of Coal Chemistry and Technology, Nur-Sultan, Kazakhstan

${ }^{2}$ Kazakh Agro Technical University named after S. Seifullin

doi: 10.36291/HIT.2019.bailina

Experiments on the use of humic preparations as a feed additive for farm animals were started in the 60s and are currently ongoing. Extensive experimental material has been accumulated, proving that the use of humates leads to an acceleration of animal growth, a decrease in the incidence and mortality rate, and an increase in their body's resistance to adverse environmental conditions. The consequence is an increase in animal productivity. Based on this, the purpose of scientific research is to develop a technology for producing a feed additive based on potassium humate. The test of a feed additive based on potassium humate was carried out on laboratory white outbred mice, with appropriate feeding and keeping conditions.

Groups of animals were selected on the basis of analogues. Before setting up the experiment, the animals were kept in quarantine for 7 days. The drug was administered on an empty stomach after a 12-hour fasting diet. Observation of animals was carried out during the entire period of the experiment.

Adult white mongrel mice with an average body weight of $23 \mathrm{~g}$ were used to determine the growth and development properties of the preparation. The study drug was administered using vodka. During the experiment, 3 groups of animals were formed (3 experiments and 1 control), 3 mice in each group. Animals received the study drug in dosages: group 1 and 2 (experience) received a $0.1 \%$ solution of the drug per 1 liter. The animals in the control group were given drinking water in similar volumes. The animals were constantly monitored, paid attention to behavior, physical activity.

The negative effect of liquid humates on the animal organism has not been identified. The animals of the experimental group, compared with the animals of the control group, were more active, mobile, well-fed food, hairline had a natural shine.

It was noted that the fluctuations in the gain in live weight between control animals and animals receiving liquid humates in the age group of animals from 1 to 3 years were 53-55 grams per day for different animals, and 154 grams per day for one to three months old day.

Thus, the test results showed that the introduction of liquid humates in the diet in addition to the main feed did not negatively affect the behavior and condition of the animals. 